\title{
PEDULI COVID-19, BERBAGI MASKER PADA PEDAGANG PASAR TRADISIONAL
}

\author{
Siska Evi Martina ${ }^{1)}$, Amila $^{2)}$, Evarina Sembiring ${ }^{3)}$ \\ Universitas Sari Mutiara Indonesia ${ }^{1)}$ \\ Universitas Sari Mutiara Indonesia ${ }^{2)}$ \\ Universitas Sari Mutiara Indonesia ${ }^{3)}$ \\ siskaevi21@gmail.com
}

\begin{abstract}
ABSTRAK
World Health Oraganization (WHO) baru-baru ini merangkum laporan-laporan transmisi virus COVID-19 dan memberikan gambaran singkat bukti-bukti yang ada tentang penularan dari orangorang bergejala (simtomatik), yang belum menunjukkan gejala (prasimtomatik), dan tidak bergejala (asimtomatik)a yang terinfeksi COVID-19. Salah satu kelompok masayarakt yang sangat rentan adalah pedagang pasar tradisional di wilayah Medan. Universitas Sari Mutiara Indonesia memiliki kepedulian untuk membantu pemerintah dalam pencegahan penularan Covid-19. Melalui kegiatan pengabdian masyarakat ini, civitas akademik membagikan masker kepada pedagang di pasar tradisional wilayah yang dekt dengan lokasi kampus. Kegiatan ini mendapat sambutan dan dukungan dari pihak kelurahan dan seluruh pedagan. Melalui kegiatan ini diharapakan kasus Covid19 tidak bertambah banyak.
\end{abstract}

Kata kunci: Covid-19; Masker; Pencegahan

\section{ABSTRACT}

The World Health Organization (WHO) recently summarized reports of the transmission of the COVID-19 virus and provides a brief overview of the available evidence of transmission from symptomatic (symptomatic) persons, asymptomatic (presymptomatic), and asymptomatic (asymptomatic) a infected with COVID-19. One of the most vulnerable groups of people is the traditional market traders in the Medan area. Sari Mutiara Indonesia University has a concern to help the government in preventing the transmission of Covid-19. Through this community service activity, the academic community distributed masks to traders in traditional markets in the area near the campus location. This activity received welcome and support from the urban village and all traders. Through this activity, the new cases will not be increase.

Key word: Covid-19; Mask; Preventive

\section{PENDAHULUAN}

COVID-19 (Coronavirus Disease2019) merupakan situasi global pandemic dan menjadi perhatian international. World Health Oraganization (WHO) sudah mejelaskan secara resmi bahwa COVID-19 adalah penyakit saluran pernafasan darurat (WHO, 2020). COVID 19 pertama kali ditemukan di Wuhan, Propinsi Hubei, China pada Desember 2019 dengan penderita pertama adalah laki-laki. Angka penderita terjangkit virus ini terus meningkat dengan cepat dan menyebar ke propinsi lain di China. Pertama kali, penemuan kasus melalui pasien dengan gejala saluran pernafasan yang cukup berbeda, seperti demam, batuk kering, dan kelemahan disertai gejala gastrointestinal lainnya. Secara resmi penemuan kasus dilaporakna di pasar tradisional pada Desember 2019 dan melibatkan $66 \%$ pegawai pasar. Sehingga, Dinas Kesehatan setempat mengumumkan status endemic pada akhir Desember 2019 dan pasar traditional tersebut harus ditutup sementara waktu. Sejak saat itu pada Januari sampai Februari 2020 dilaporkan ribuan orang terinfeksi dan memiliki gejala terjangkit virus novel corona 19 ini. Selain itu, penyakit ini menjadi sangat cepat menyebar 
dibeberapa negara seperti Thailand, Korea, Vietnam, German, United State of America, dan Singapore. Selanjutnya phatogen atau virus tersebut diidentifikasi sebagai novel beta-coronavirus dinamai coronavirus disease.

World Health Organization (WHO) melaporkan pada 4 Mei 2020, total 3.445.894 orang telah dilaporkan dikonfirmasi untuk penyakit COVID19 secara global. Di antara ini, ada 239.604 kematian yang dilaporkan terkait dengan COVID-19. Sedangkan kasus virus corona di Asia Tenggara mencapai 293 ribu kasus yang sudah terkonfirmasi dan terdapat 105 kasus jiwa yang mengalami kematian. Indonesia merupakan negara berkembang dengan jumlah penduduk yang tinggi dan sebagai negara tujuan touris asing membuat angka trasnportasi global yang tinggi. Beberapa negara telah melaporkan penemuan kasus COVID-19 sejak Januari hingga Februai, namun pemerintah Indonesia menyatakan belum mengidentifikasi adanya kasus penderita gejala COVID 19.

Pada awal Maret 2020, Presiden Indonesia mengumumkan penemuan dua kasus pasien positif COVID-19. Sejak itu, penyebaran kasus COVID di Indonesia dari bulan Maret hingga awal Junni 2020 mengalami penyebaran yang sangat cepat. Hal ini ditunjukkan dengan sebaran kasus COVID-19 saat ini sudah menyebar secara merata di 34 provinsi di Indonesia. Kondisi ini dimonitoring oleh Gugus Tugas Percepatan Penanganan COVID-19 dalam tiga kategori yaitu berdasarkan penambahan kasus baru per hari, penambahan kasus meninggal per hari dan penambahan kasus sembuh per hari (Gugus Tugas Percepatan Pencegahan COVID-19, 2020).

Sejak ditemukan dua (2) kasus warga negara Indonesia yang positif terkena covid pada bulan Maret 2020, penambahan kasus baru per hari mengalami peningkatan hingga awal Juni 2020. Data terakhir yang ditemukan pada tanggal 2 Juni 2020 pukul 16.00 WIB, kasus positif COVID-19 terkonfirmasi di seluruh provinsi sebanyak 27.549 kasus yang menunjukkan adanya pertambahan sebanyak 609 kasus dari hari sebelumnya. Pasien yang sedang dalam perawatan sebesar $65,2 \%$, pasien yang sembuh sebesar $28,8 \%$ dan pasien yang meninggal dunia sebesar $6 \%$ (Gugus Tugas Percepatan Pencegahan COVID-19, 2020).

Sedangkan kasus COVID-19 di Sumatera Utara dilaporkan juga cukup tinggi. Menurut Gugus Tugas Percepatan Penangan COVID 19 Sumatera Utara dilaporakan sampai tanggal 2 Juni 2020, 418 kasus positif, 144 pasien dalam pengawasan, 150 pasien sembuh, dan 41 pasien meninggal (Gugus Tugas COVID-19 Sumatera Utara, 2020).

Informasi yang ada saat ini mengindikasikan bahwa dua cara utama transmisi virus COVID-19 adalah percikan (droplet) saluran pernapasan dan kontak. Percikan saluran pernapasan dihasilkan saat seseorang batuk atau bersin. Setiap orang yang berada dalam kontak erat (dalam radius $1 \mathrm{~m}$ ) dengan orang yang menunjukkan gejala-gejala gangguan pernapasan (batuk, bersin) berisiko terpapar percikan saluran pernapasan yang kemungkinan dapat menyebabkan infeksi (infeksius). Percikan juga dapat jatuh ke permukaan benda di mana virus tetap aktif; oleh karena itu, lingkungan sekitar terdekat dari orang yang terinfeksi dapat menjadi sumber penularan (penularan kontak) (Water, Sanitation, hygiene, and waste management for COVID-19). 
WHO baru-baru ini merangkum laporan-laporan transmisi virus COVID-19 dan memberikan gambaran singkat bukti-bukti yang ada tentang penularan dari orang-orang bergejala (simtomatik), yang belum menunjukkan gejala (prasimtomatik), dan tidak bergejala (asimtomatik)a yang terinfeksi COVID-19 (informasi lengkap tersedia dalam WHO COVID19 Sitrep 79). Bukti yang ada saat ini mengindikasikan bahwa penyakit ini umumnya ditularkan oleh kasus-kasus terkonfirmasi laboratorium simtomatik. Rata-rata masa inkubasi COVID-19, yaitu jangka waktu mulai terpapar virus sampai dengan munculnya (onset) gejala, adalah 5-6 hari, tetapi masa inkubasi ini bisa mencapai 14 hari. Jangka waktu ini juga disebut sebagai masa "prasimtomatik", dan beberapa orang yang terinfeksi dalam masa prasimtomatik ini dapat menjadi sumber penularan dan mentransmisikannya ke orang lain. Beberapa laporan dalam jumlah terbatas mencatat terjadinya penularan prasimtomatik ini melalui pelacakan kontak dan penyelidikan pada kelompok (klaster) kasus terkonfirmasi. Hal ini didukung oleh data yang mengindikasikan bahwa beberapa orang dapat menunjukkan hasil tes positif COVID-19 dari 1-3 hari sebelum menunjukkan adanya gejala. Oleh karena itu, ada kemungkinan orang yang terinfeksi COVID-19 dapat mentransmisikan virus tersebut sebelum munculnya gejala. Penting disadari bahwa penularan prasimtomatik terjadi karena adanya penyebaran virus melalui percikan yang dapat menyebabkan infeksi atau melalui sentuhan dengan permukaan benda yang terkontaminasi virus ini. WHO terus memantau bukti-bukti baru mengenai topik yang penting ini dan akan memberikan perkembangan seiring semakin tersedianya informasi.

\section{METODE PELAKSANAAN}

Secara ringkas metode kegiatan pengabdian masyarakat ini menggunakan metode sebagai berikut:

1. Survei lapangan

Survei ini dilakukan dengan melakukan kunjungan langsung ke tempat pengabdian masyarakat. Kegiatan survei ini bertujuan untuk melihat secara langsung usia rata-rata penghuni panti jompo dan kesiapan mereka saat mengikuti kegiatan sosialisasi infeksi corona virus.

2. Koordinasi dengan Kepala Kelurhana Kampung Lalang dan Penanggung Jawab Pasar Kampung Lalang untuk pengurusan proses perizinan kepada pedagan pasar kampung lalang. Selanjutnya menentukan tempat dan waktu yang tepat untuk dilakukan kegiatan pembagian masker ini. Kegiatan dilakukan pada tanggal 7-8 Mei 2020.

3. Sosialisasi kegiatan pengabdian masyarakat kepada seluruh pedangang pasar kampung lalang Kegiatan ini bertujuan untuk menyampaikan pengetahuan dan pemahaman mengenai infeksi corona virus dan pencegahan penularan virus ini kepada seluruh pedangang dan pembeli.

4. Pelaksanaan kegiatan Kegiatan dilakukan melalui sosialisasi Covid-19 dan pencegahan 


$\begin{array}{lrr}\text { dengan } & \text { penggunaan } & \text { masker } \\ \text { dengan benar. } & \text { Seluruh } \\ \text { pedagang juga } & \text { diberikan } \\ \text { masker dan } & \text { langsung } \\ \text { mempraktekan } & \text { cara } \\ \text { penggunaan masker } & \text { dengan } \\ \text { benar. } & & \end{array}$

\section{HASIL DAN PEMBAHASAN}

\section{A. Gambaran Pasar Tradisional Kampung Lalang}

Pasar kampung lalang terletak di Jl Gatot Subroto, Pasar ini memiliki dua akses jalan besar yaitu jalan Gatot Subroto dan jalan Kelambir V. Pasar kampung lalang merupakan pasar tradisional yang selalu ramai pengunjung, dengan jumlah pedagan lebih dari 300 pedagang. Pasar ini terlihat kumuh, kotor, basah, dan padat. Banyak sampah menumpuk di beberapa tempat dan tidak pada tempatnya. Pedagang di Pasar kampung lalang tidak hanya berjualan di kios atau tempat tersedia, tetapi sangat banyak pedagang yang berjualan di pinggir jalan dan tidak teratur. Hal ini membuat masalah kemacetan yang sudah menjadi masalah yang tidak pernah bisa terselesaikan oleh Pemerintah Kota Medan. Sudah beberapa kali dilakukan pembinaan dan penertiban tetapi pedagan masih saja berjualan di pinggir jalan.

Pada situasi pandemi COVID19 saat ini, pasar kampung lalang merupakan tempat yang sangat rentan terjadinya penularan. Karakteristik masyarakat dan pedagang yang masih kurang menyadari tentang penularan COVID-19 dan tidak terlalu memahami maksud himbauan pemerintah tentang pembatasan jarak sosial atau social distancing. Terlihat bahwa sampai saat ini pasar kampung lalang selalu ramai pengunjunng dan semua pembeli dan pedagang tidak ada batas jaarak karena wilayah lokasi berjualan yang sangat sempit. Selain itu, pembeli dan pedagang juga tidak semua menggunakan masker.

Saat dilakukan wawancara singkat kepada beberapa pedagang dan pembeli di pasar kampung lalang, dapat disimpulkan bahwa masyarakat masih kurang sadar dan perhatian terhadap penularan COVID-19 sehingga kurang memahami pencegahan yang dapat dilakukan. Masyarakat juga kurang memahami bahwa penggunaan masker merupakan salah satu cara pencegahan COVID- 19 .

\section{B. Kesadaran Bagi Masyarakat}

Penelitian tentang influenza, penyakit serupa influenza (influenza-like illness), dan coronavirus pada manusia memberi bukti bahwa penggunaan masker medis dapat mencegah penyebaran percikan yang dapat menyebabkan infeksi dari orang yang terinfeksi ke orang lain dan kemungkinan kontaminasi lingkungan akibat percikan ini.13 Bukti bahwa penggunaan masker medis oleh orang sehat di dalam rumah atau oleh orang-orang yang melakukan kontak dengan pasien, atau oleh orang-orang di tengah perkumpulan besar yang berfungsi sebagai pencegahan masih terbatas.14-23 Namun, saat ini belum ada bukti bahwa mengenakan masker (baik masker medis atau jenis lainnya) oleh orang sehat di tengah masyarakat 
secara umum, termasuk penggunaan masker secara bersama-sama pada masyarakat luas, dapat mencegah masyarakat dari infeksi virus saluran pernapasan, termasuk COVID-19. Di beberapa negara, masker dipakai sesuai dengan kebiasaan setempat atau sesuai anjuran otoritas nasional dalam konteks COVID-19. Dalam situasi demikian, praktik terbaik cara menggunakan, melepas, dan membuang masker serta membersihkan tangan setelah melepas masker harus diikuti.

\section{Kebijakan Penggunaan Masker}

Sebagaimana disebutkan di atas, penggunaan masker secara meluas oleh orang-orang sehat di tengah masyarakat tidak didukung oleh bukti yang ada dan menyebabkan ketidakpastian serta risiko-risiko yang bersifat kritis. WHO memberikan anjuran berikut kepada para pengambil keputusan sehingga dapat menerapkan pendekatan berdasarkan risiko. Para pengambil keputusan disarankan mempertimbangkan hal-hal berikut ini:

1. Tujuan penggunaan masker: dasar dan alasan penggunaan masker harus jelas - apakah masker digunakan sebagai pengendalian sumber infeksi (digunakan oleh orang yang terinfeksi) atau pencegahan COVID-19 (digunakan oleh orang sehat)

2. Risiko paparan terhadap virus COVID-19 dalam konteks setempat:

- Populasi: situasi epidemiologi tentang

bagaimana virus bersirkulasi (misal, klaster kasus atau penularan di masyarakat), serta kapasitas surveilans dan pemeriksaan setempat (misal, pelacakan kontak dan tindak lanjut, kemampuan melakukan pemeriksaan)

- Individu: bekerja dengan berkontak erat dengan masyarakat (misal, kader kesehatan, kasir)

3. Kerentanan orang/populasi untuk terkena penyakit atau berisiko lebih tinggi meninggal, misal, orangorang dengan penyakit lainnya (komorbid), seperti penyakit jantung (kardiovaskular) atau diabetes mellitus, dan kelompok lanjut usia.

4. Situasi kehidupan populasi terkait kepadatan penduduk, seberapa jauh prinsip menjaga jarak fisik dapat dilakukan (misal, di bis yang penuh), dan risiko penyebaran cepat (misal, tempat tertutup, pemukiman kumuh, asrama/tempat serupa asrama).

5. Keberlangsungan: ketersediaan dan harga masker, dan penerimaan orang terhadap masker

6. Jenis masker: masker medis atau masker nonmedis (lihat di bawah)

Selain faktor-faktor ini, potensi manfaat penggunaan masker oleh orang yang sehat di tengah masyarakat mencakup penurunan kemungkinan risiko paparan dari orang yang terinfeksi selama masa "prasimtomatik" dan stigmatisasi orang-orang yang mengenakan masker untuk pengendalian sumber infeksi.

Namun, kemungkinankemungkinan risiko berikut harus diperhatikan dengan cermat dalam setiap proses pengambilan 
keputusan:

- kontaminasi oleh diri sendiri dapat terjadi melalui sentuhan dan penggunaan kembali masker yang terkontaminasi.

- kemungkinan kesulitan bernapas, tergantung jenis masker yang digunakan.

- rasa aman yang semu, yang menimbulkan kemungkinan penurunan kepatuhan dalam menjalankan langkah-langkah pencegahan lain seperti menjaga jarak fisik dan membersihkan tangan.

- pengalihan ketersediaan masker serta kurangnya masker bagi tenaga kesehatan yang disebabkannya.

- pengalihan sumber daya dari langkah-langkah kesehatan bersama yang efektif, seperti menjaga kebersihan tangan.

Terlepas dari pendekatan mana pun yang diambil, penyusunan strategi komunikasi yang kuat penting dilakukan guna menjelaskan situasi, kriteria, dan alasan keputusan yang diambil kepada masyarakat. Masyarakat harus mendapatkan instruksi yang jelas tentang masker jenis apa yang digunakan, kapan dan bagaimana caranya (lihat bagian tatalaksana masker), dan pentingnya terus menjalankan langkah-langkah PPI lain dengan ketat (misal, menjaga kebersihan tangan, menjaga jarak fisik, dll.).

\section{Cara Menggunakan Masker Yang} Benar

Masker sangat penting digunakan orang sakit (demam/batuk/bersin) atau mereka yang merawat orang sakit dan yang beraktifitas di luar rumah. Berikut panduan cara menggunakan masker yang tepat.

Tenaga kesehatan, orang sakit dan orang yang merawat orang sakit menggunakan masker medis. Orang sehat cukup menggunakan masker kain.

Berikut panduan cara menggunakan masker yang tepat:

a. Sebelum memamasang masker, cuci tangan pakai sabun dan air mengalir (minimal 20 detik) atau bila tidak tersedia, gunakan cairan pembersih tangan (minimal alkohol $60 \%$ ).

b. Pasang masker untuk menutupi mulut dan hidung dan pastikan tidak ada sela natara wajah dan masker.

c. Hindari menyentuh masker saat digunakan; bila tersentuh, cuci tangan pakai sabun dan air mengalir selama 20 detik atau bila tidak ada, cairan pembersih tangan (minmal alkohol 60\%).

d. Ganti masker yang basah atau lembab dengan masker baru. Masker medis hanya boleh digunakan satu kali saja. Masker kain dapat digunakan berulang kali.

e. Untuk membuka masker: lepaskan dari belakang. Jangan menyentuh bagian depan masker; untuk masker $1 \mathrm{x}$ pakai, buang segera di tempat sampah tertutup atau kantong plastik.

Untuk masker kain, segera cuci dengan deterjen. Untuk memasang masker baru, ikuti poin pertama. 


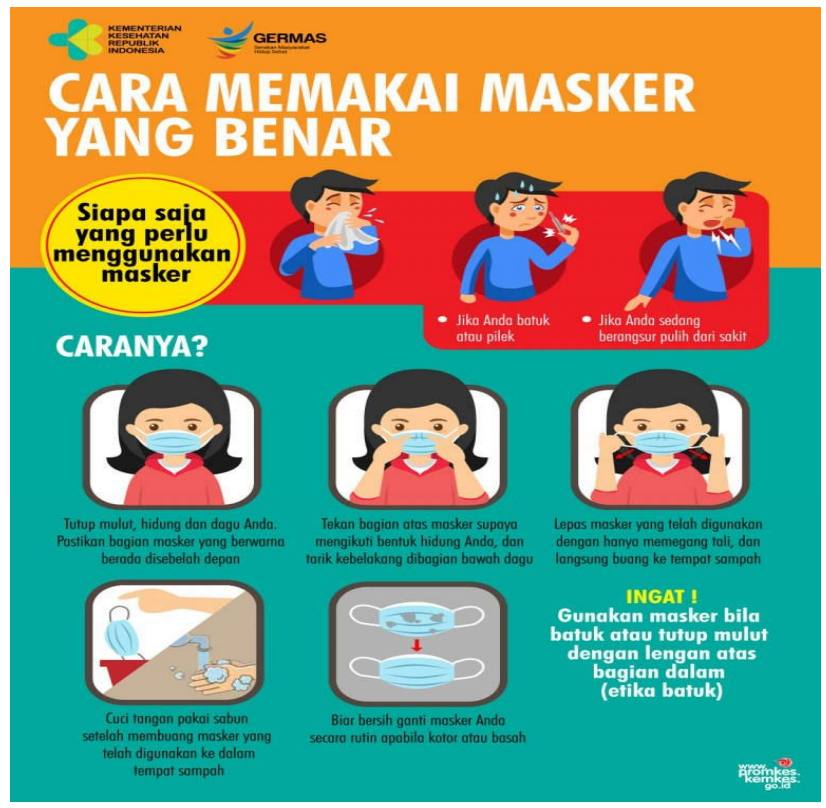

Gambar 1. Cara penggunaan masker yang benar

Sumber: https://covid19.go.id/edukasi/masyarakat-umum/cara-memakai-masker-

\section{yang-benar2}

\section{E. Kegiatan Pembagian Masker bagi Pedagang Pasar \\ Kampung Lalang}

Pecegahan penyebaran virus COVID-19 ini salah satunya adalah dengan penggunaan masker. Salah satu perguruan tinggi Universitas Sari Mutiara Indonesia, Medan melakukan kegiatan membagikan masker gratis kepada para pedangang di pasar tradisional Kampung Lalang. Penggunaan masker ini bertujuan sebagai antisipasi merebaknya virus corona. Dosen Universitas Sari Mutiara Indonesia Medan, melakukan kegiatan pembagian masker ini sebagai bentuk antisipasi agar kesehatan pendagang tetap terjaga. Jadi ini, tidak hanya soal virus corona yang sedang booming, tapi juga penyakit lain seperti flu atau pilek yang bisa menular. Kegiatan pembagian masker gratis yang dilakukan oleh perguruan tinggi Universitas Sari Mutiara tersebut mendapatkan antusias yang baik dan di sambut hangat oleh masyarakat dan para pedangan di pasar tradisonal tersebut. Kegiatan ini juga mengajarkan kepada pedangan dan masyarakat dalam menggunakan masker yang baik dan benar dan diberi arahan agar para pedangan selalu memakai masker saat berjualan dan mencuci tangan dengan baik dan benar setelah bertansaksi dengan masyarakat agar menghabat penyebaran virus corona.

Melalui prosedur bersama pihak Kelurahan Kampung Lalang, pembagian masker berjalan dengan lancar. Pedagang menyambut antusias 
dan berterma kasih atas masker yang diberikan secara gratis dan informasi yang diberikan membuat pedagang merasa lebih paham bahwa COVID19 bisa menular dimana saja sehingga sangat penting untuk menggunakan masker.

Meskipun ada beberapa pedagang awalnya masih bingung tentang COVID-19 dan awalnya tidak mau menerima masker yang diberikan karena takut disuruh bayar. Namun setelah dijelaskan pedagang sangat berterima kasih dan berjanji akan menggunakan masker setiap hari.

Program ini diharapkan dapat membantu pemerintah untuk menanggulangi penularan COID-19 khususnya bagi masyarakat yang rentan seperti pedagan pasar tradisional yang kotor. Program ini akan ditindak lanjuti oleh pihak Kelurahan Kampung Lalang untuk memonitor pedagang menggunakan masker dengan benar.

\section{KESIMPULAN}

Kegiatan pengabdian masyarakat ini merupakan wujud kepedulian terhadap situasi pendemi Covid-19 yang melanda Indonesia. Masyarakat yang sangat rentan terhadap penularan Covid-19 adalah para pedagang di pasar tradisioanl Kampung Lalang dimana pasar tersebut dangat padat pedagang dan pembeli, kurangnya informasi pencegahan Coivd19 dan kesadatan penggunaan masker. Maka dari itu melalui kegiatan pembagian masker ini diharapkan penularan Covid-19 dapat dioptimalkan oleh pedangan pasar Kampung Lalang. Sehingga tidak menambah jumlah kasus baru Covid-19 dan membantu pemerintah dalam upaya percepetan pencegahan penularan Covid-19. 

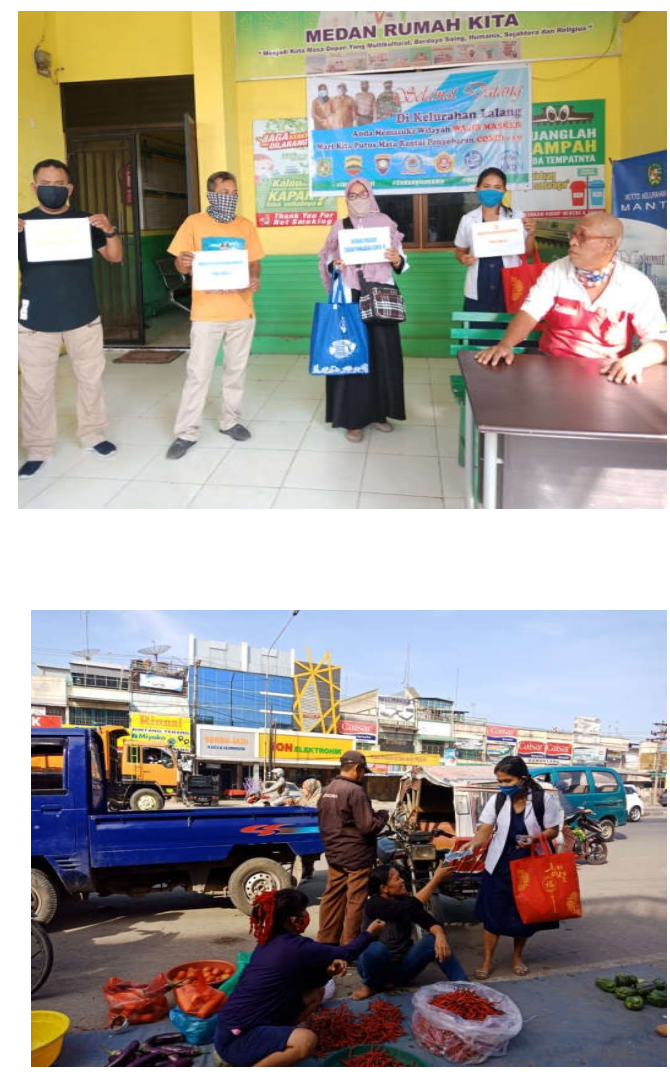

Gambar 2. Edukasi dan Pembagian Masker

\section{REFERENSI}

Coronavirusdisese2019(COVID19)Situation Report- 73.

https://www.who.int/docs/default source/coronaviruse/situati onreports/20200402-sitrep73-

covid19.pdf?sfvrsn $=5 \mathrm{ae} 25 \mathrm{~b}$ c7_6

Gugus Tugas Percepatan
Penanganan COVID-19.
(2020). Data Sebaran 2 Juni
2020. Tersedia di
https://covid19.go.id/peta-
$\underline{\text { sebaran }}$
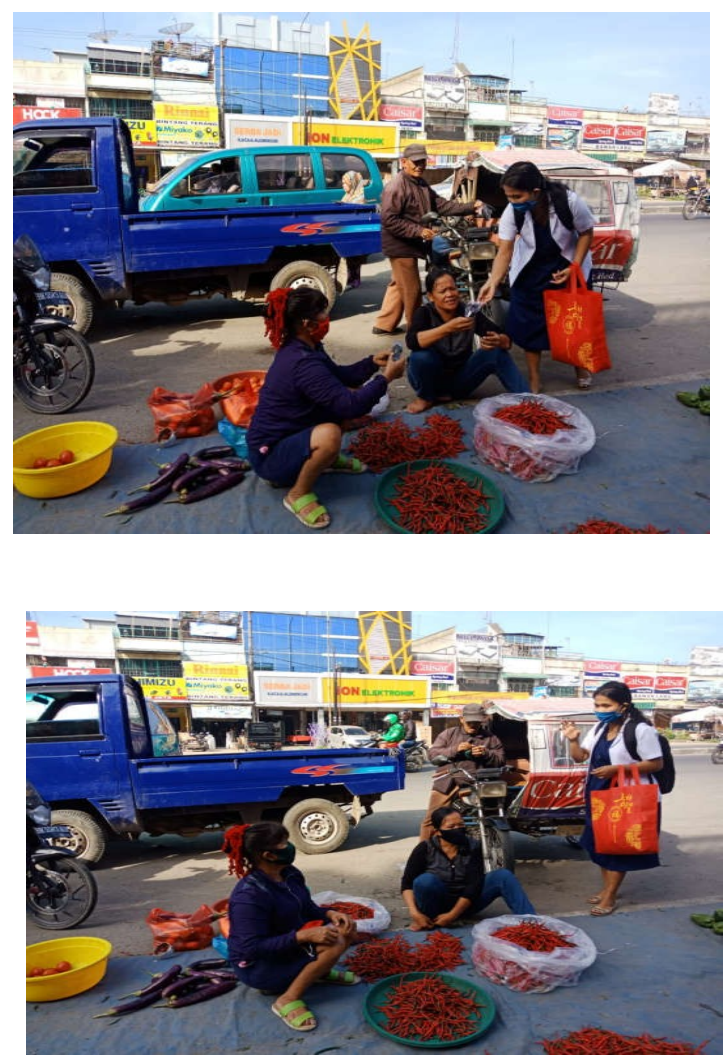

Gambar 3. Pembagian masker kepada pedagan pasar

\section{Gugus Tugas Percepatan Penanganan COVID-19 Sumatera Utara. (2020). Situasi COVID-19 Di Materi Edukasi Masyarakat Umum .(2020). Cara Memakai Masker yang Benar. Tersedia di https://covid19.go.id/eduka si/masyarakat-umum/cara- memakai-masker-yang- $\underline{\text { benar2 }}$}

Water,sanitation,hygieneandwast e managementforCOVID19

https://www.who.int/public ationsdetail/watersanitation-hygiene-and- 
wastemanagement- $\quad$ forcovid-19

World Health Organization. Report of the WHO-China Joint Mission on Coronavirus Disease 2019 (COVID-19) 16-24 February 2020 [Internet]. Jenewa: World Health Organization; $\quad 2020$ Tersedia di: https://www.who.int/docs/d efaultsource/coronaviruse/ who-china- jointmissionon- covid-19-finalreport.pdf

World Health Organization. (2020). Coronavirus disease (COVID-19) Situation Report- 108 Data as received by WHO from national authorities by 10:00 CEST, 7 May 2020. Tersedia dari https://www.who.int/docs/d efault-

source/coronaviruse/situati on-reports/20200507covid19-sitrep108.pdf?sfvrsn $=44 \mathrm{cc} 8 \mathrm{ed} 8$ $\underline{2}$

World Health Organization. Novel Coronavirus (2019nCoV). Tersedia pada https://www.who.int/emerg encies/diseases/novelcoronavirus-2019. 